\title{
STUDIA I MATERIALY
}

\author{
Dział A
}

\section{ARCHEOLOGIA POWSZECHNA}

\section{ROLA DZIEGCIU I KORY \\ W ZDOBNICTWIE NACZYŃ NEOLITYCZNYCH. LINGWISTYCZNY PRZYCZYNEK DO PRAHISTORII ESTETYKI}

\author{
IMPORTANCE OF BIRCH TAR AND BARK \\ IN THE DECORATION OF NEOLITHIC VESSELS. \\ A LINGUISTIC CONTRIBUTION TO THE PREHISTORY OF AESTHETICS
}

\author{
Andrzej P. Kowalski \\ Zakład Etnologii, Uniwersytet Mikołaja Kopernika \\ ul. Gagarina 5, 87-100 Toruń, Poland
}

\begin{abstract}
The article presents hypothetical interpretation of expressions connected with the use of tar and bark in the decoration of Central European Neolithic vessels. The data of Indoeuropean linguistics make it possible to discern sources of important aesthetic categories in reference to the methods of bark working and use. Some traditional expressions of beauty and grace derive from the names of techniques of vegetable dye use and from birch tar glossiness. The linguistic evidence presented above gives an empirical support to archaeological observations. It constitutes the basis of "genealogical" analysis in which prehistory of production is treated as a culture-practical context of formation of later aesthetic categories.
\end{abstract}

Badania nad ceramiką neolityczną prowadzone przez archeologów i przedstawicieli nauk przyrodniczych pozwoliły ustalić, że niektóre wspólnoty paleoagrarne Niżu Europejskiego kultywowały zwyczaj wykorzystywania dziegciu i kory brzozowej w zdobnictwie naczyń'. Niezależnie od walorów poznawczych, jakie spostrzeżenia te wnoszą do rozwoju problematyki czysto archeologicznej, warto wska-

\footnotetext{
${ }^{I}$ Langer, Kośko 1999.
} 
zać ich efektywność na obszarze dociekań z zakresu prahistorii estetyki. Jak wiadomo, klasyczna refleksja estetyczna obejmuje dziedzinę doświadczenia zmysłowego przedmiotów wyposażonych w jakości lub wartości estetyczne, które stanowią otzw. „sprawności” owych przedmiotów do wzbudzania postaw estetycznych (upodobania) ${ }^{2}$. W przypadku interpretacji artefaktów prahistorycznych granice tej refleksji zaznaczają się szczególnie ostro. Wynika to nie tylko $\mathrm{z}$ oczywistych względów empirycznych, ale i z tego, że struktura waloryzacji doświadczeń estetycznych nie była we wspólnotach wczesnotradycyjnych przedmiotem osobnej, wewnątrzgrupowej charakterystyki. Najprawdopodobniej w kulturowo określonej dziedzinie doznania zmysłowego przedstawicieli tych wspólnot, w naoczności opanowanej przez doświadczenie magiczne, nie zachodził proces czystej percepcji. Oznacza to, że przedmioty dla nas obecne w postaci fenomenów zmysłowych (albo zbioru cech poddających się wyczerpującemu opisowi fenomenalistycznemu) mogły być niegdyś odbierane jako przedmioty wyposażone w „dodatkowe” jakości, którym percepcja naukowa odmawia prawa bytu ${ }^{3}$.

Prahistoria estetyki jest zatem skromną próbą określenia owych „dodatkowych" jakości, zmierza do ukazania wyobrażeń sekundujących działaniom wytwórczym we wspólnotach wczesnotradycyjnych. Pewnym wsparciem dla tak projektowanego zamierzenia, zapewne niedoskonałym, ale zasługującym na przyjęcie, są rekonstrukcje lingwistyczne. Chodzi tu o leksykę indoeuropejska, której pierwotną produktywność można relatywizować do realiów kulturowych epoki neolitu. Wiarygodność takiej kwalifikacji chronologicznej świadectw leksykalnych zdają się wzmacniać analizy porównawcze odwołujące się do pojęcia starszej, nostartyckiej wspólnoty językowej, datowanej na okres wyprzedzający pojawienie się kultury agrarnej ${ }^{4}$. Biorąc pod uwagę nasuwające się tu obiekcje co do prawomocności rekonstrukcji lingwistycznych, proponowane niżej interpretacje interesujących nas fragmentów dawnego „świata wyobrażeń" należy traktować wyłącznie w kategoriach heurystycznych.

\section{A. ZDOBIENIE NACZYŃ DZIEGCIEM}

\section{A. 1. UTOŻSAMIENIE ZNACZENIA NIEKTÓRYCH NAZW DRZEWA} ZE ZNACZENIEM DZIEGCIU W TRADYCJI INDOEUROPEJSKIEJ

Szczególna wartość dziegciu w wytwórczości wspólnot wczesnotradycyjnych znalazła swoje odzwierciedlenie w słownictwie indoeuropejskim. Okazuje się, że niektóre nazwy drzew zostały urobione od nazwy uzyskiwanej z nich kory, żywicy lub smoły. Jednak ściśle „technologiczny” aspekt kulturowej motywacji semantyki takiej nomenklatury jest pozorny. W czasach kształtowania się założeń tej semanty-

\footnotetext{
${ }^{2}$ Ingarden 1970, s. 288 n.

${ }^{3}$ Kowalski 2001, s. 49-58.

${ }^{4}$ Bomhard, Kerns 1994.
} 
ki zarówno kora, jak i dziegieć miały również zastosowanie pozautylitarne i - jak zobaczymy - były nośnikami sensów proestetycznych.

[1] nost. **kojw/al 'brzoza': ural. kojwA 'brzoza', ałt. kib (a) 'brzoza lub brzost", albo drzewo dostarczające korę', ? pol. żywica ${ }^{5}$.

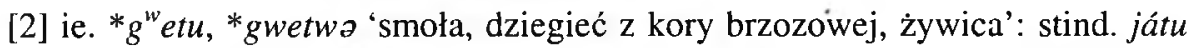
'lak, guma', stnord. kvầo 'drzewo żywiczne, smolne', wal. bedw 'brzoza' $\left(<{ }^{*} g^{w}\right.$ etweH $\left.a^{-}\right)$, łac. betulla 'brzoza', łac. bitūmen 'żywica', stang. cwidu 'gumowy', swn. kuti 'klej', pol. kit' .

[3] ie. *piks 'smoła, żywica': grec. píssa, pítta (*pikya) 'smoła', łac. pix, picis, picula 'smoła', swn. pëh 'smoła', stang. pik 'smoła', śirl. piec 'smoła', lit. pikis 'smoła', psł. *pbklъ 'smoła' (> stpol. piekty, pol. piekto)'

\section{A.2. WYOBRAŻENIA ŁACZACE SMAROWANIE DZIEGCIEM Z KREOW ANIEM SENSÓW MAGICZNYCH I PROESTETYCZNYCH}

Zdobienie naczyń ceramicznych dziegciem można zaliczyć do tego samego kompleksu czynności co nakładanie angoby albo smarowanie i uszczelnianie smołą pojemników skórzanych i koszy. W starożytnym Egipcie i w Mezopotamii często używano rozmaitych rodzajów kitu i smoły (bitumenu) do uszczelniania, a częściowo do polerowania naczyń ${ }^{8}$. Natłuszczanie i polerowanie powierzchni zasobników

Na zapytanie Redaktora FPP Autor wyjaśnił listem z dnia 26.04.2001 r.: „Chciałbym rozwiać wątpliwości, które nasunęły się Panu Profesorowi podczas lektury mojego tekstu. Oczywiście wiem, że brzost to inny gatunek drzewa niż brzoza. Jednak rozróżnienie tych gatunków funkcjonuje z uwagi na wspólczesne oznaczenia botaniczne. Mnie interesuje klasyfikacja kulturowa, tzn. „etnobotaniczna” utrwalona w słownictwie i wyobrażeniach. Prof. T. Dunin-Karwicka, autorka etnologicznych rozpraw dotyczących kultu drzew w Europie, potwierdziła, że w folklorze często traktowano nazwy drzew ,niekonsekwentnie". Okazuje się bowiem, że $w$ wielu przypadkach na oznaczenie rozmaitych gatunków drzew używano tego samego słowa, szczególnie gdy leksemy miały wspólną motywację etymologiczna. Tak właśnie jest w przypadku brzozy i brzostu. Dobrym przykładem tego typu komplikacji jest znaczenie prasłowiańskiego wyrazu gъrnъ. W jego polu semantycznym znajdują się takie odniesienia przedmiotowe, jak: 'ognisko', 'garnek', 'piec'. Zamienne stosowanie tych znaczeń dokumentują niemal wszystkie języki słowiańskie, zwłaszcza dialekty wschodnie. Według archeologa piec, palenisko i garnek to zupelnie różne kategorie obiektów. Dla każdej z tych kategorii z pewnością stworzono osobne klasyfikacje lub typologie. Tymczasem u dawnych Słowian rozróżnienie nazewnicze tych obiektów musiało przebiegać inaczej, tzn. nie musialo pokrywać się z podzialami. które archeolog traktuje jako oczywiste i odwieczne. Prawdopodobnie mamy tu do czynienia z klasą obiektów kojarzonych ogólnie z żarem - przynajmniej tak sugerują dane leksykalne. Przykłady tego rodzaju niewspółmierności w zakresie kulturowych klasyfikacji badacza i podmiotów badanych można przytaczać bez końca".

${ }^{5}$ Illič-Svitič 1971, hipoteza 170.

${ }^{6}$ Mann 1987, s. 358; Delamarre 1984, s. 169; Mallory, Adams 1997, s. 500; Walde, Hofmann 1938 , s. 107.

${ }^{7}$ Pokorny 1959, s. 794; Walde, Hofmann 1954, s. 312; Delamarre 1984, s. 172.

${ }^{8}$ Forbes 1956, s. 256; Semenov, Korobkova 1983, s. 229-230. 
skórzanych, a następnie ścianek naczyń ceramicznych, wykazuje nie tylko określoną tradycję technologiczną ale również pewną ciągłość wczesnotradycyjnych wyobrażeń. Swego czasu R. Meringer sugerował, że maksyma „tłuste jest piękne” należy do najstarszych, urzeczywistnianych już od paleolitu zasad estetycznych (por. związek słów okrasa i krasić). Na podstawie przytaczanych świadectw etnologicznych i danych lingwistycznych, Meringer żywotnością tej maksymy uzasadniał częste przykłady ukazywania obfitych kształtów kobiet w pradziejowej plastyce figuralnej, a także powszechny zwyczaj wykorzystywania maści, głównie w celach higienicznych i kosmetycznych".

W tradycji wczesnogreckiej, zwłaszcza w eposach homeryckich, piękno nie było wartością idealną dostrzeganą w przedmiotach, lecz rodzajem wdzięku, jakim bogowie obdarzają obiekty wzbudzające zachwyt. Wdzięk taki był zmysłowo dostępną jakością, ujawniał się $w$ wyniku zlewania na przedmioty $i$ ludzi specjalnej substancji. W języku Homera nadawanie tak rozumianego „piękna” jest równoznaczne właśnie z oblewaniem (katacheue), tudzież smarowaniem owym wdziękiem, namaszczaniem „boskim pięknidłem” (np. Odyseja XVIII, 192-193: kalà káthēren ämbrsíō). Wdzięk był tożsamy z nadzwyczajną, płynną powłoką dająca blask, który przewyższał połysk polerowanej kości słoniowej. Tak więc nacieranie tłustymi substancjami, polerowanie przedmiotów było w czasach Homera uważane za działanie inspirowane boską wolą nadawania „piękna” albo za czynność, w trakcie której urzeczywistnia się boski lub dajmoniczny wpływ. Nie można wykluczyć, że tradycja homerycka stanowi świadectwo bardzo archaicznego wyobrażenia. „Piękno” wprawdzie stanowi zmysłowy i materialny składnik rzeczy, jednak wartościowość owego „piękna” i waloryzacja tej rzeczy dokonywana w obszarze naoczności magicznej uwzględnia ową pozazmysłową, boską determinację jej dostrzegalnych jakości ,przedmiotowych”.

Dodatkowym wzmocnieniem wyrażonej tu hipotezy mogą być kolejne ustalenia z zakresu indoeuropeistyki. Otóż T.V. Gamkrelidze i V.V. Ivanov starali się wykazać związek leksemu [3] z nazwą sosny jako drzewa dającego żywicę i nadającego się do wyrobu smoły. Ich zdaniem ie. *peuka 'sosna' stanowi rozszerzenie rdzenia *phey-, *phi-, a zwłaszcza *pey(ə)-, *pF- 'być tłustym, mazistym’ i dlatego można genetycznie wiązać go z takimi formami, jak: ie. *pi-tus 'sosna' < 'drzewo żywicz-

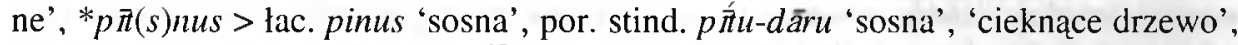
łac. p $\bar{\pi} u \pi l a$ 'wydzielina, flegma' ${ }^{10}$. W perspektywie interesujących nas tu zagadnień należy zauważyć, że uczeni ci wskazują na związek nazwy sosny, jako drzewa dostarczającego smoły, z leksemem ie. *peik- oznaczającym malowanie, barwienie, pisanie. Za postulowana przez nich identyfikacją bądź kontaminacją semantyczna leksemów *peukāa 'sosna' *piks 'smoła, żywica' *peik- 'barwić, malować' kryje

${ }^{9}$ Meringer 1913, s. 151 n.; zob. też Leroi-Gourhan 1971, s. $231 \mathrm{n}$.

${ }^{10}$ Gamkrelidze, Ivanov 1984, s. 631, 632; Pokorny 1959, s. 793-794: Walde, Hofmann 1954, s. 308; Delamarre 1984, s. 172. 
się sugestia, że smoła i dziegieć mogły stanowić preparat służący do celów zdobniczych. Smołę zatem wykorzystywano dawniej ,jako «czarną farbę roślinną» do nanoszenia określonych symbolicznych piktograficznych znaków i rysunków, a później także dla pisma""1. Według C. Bucka, w tradycji germańskiej barwienie przedmiotów na czerwono miało sens magiczny, na co wskazywać ma etymologiczne powinowactwo wyrazu stang. tēafor 'pigment, czerwona pasta $\mathrm{z}$ rudy' ze słowem niem. Zauber 'czary, magia'12.

Do niezmiernie ważnych i proestetycznie nacechowanych czynności realizowanych przez pradziejowych wytwórców należały wszelkie działania polegające na lepieniu, przylepianiu, mocowaniu i obmazywaniu. Jest to zestaw fakultatywnych działań charakteryzujących pracę garncarza wylepiającego naczynie $\mathrm{z}$ gliny, nasączającego jego ścianki tłuszczem, zdobiącego jego powierzchnię barwnymi pastami i być może także aplikacjami z pasm kory lub łyka. Wszystkie te operacje były zarazem środkami urzeczywistniania „piękna”.

[4] ie. *leipō 'lepić, przyklejać, przymocowywać', 'obmazywać tłuszczem, mazać, plamić', 'przylegać do czego': het. lipp- 'smarować, malować', grec. aleiphein 'namaszczać skórę oliwa', pol. lepić13. Na uwagę zasługują należące tu odpowiedniki germańskie, np. ang. life 'życie'. Być może chodziło tu o wyobrażenie życia ujmowanego jako ciągłość dokonująca się poprzez przyklejanie, mocowanie. Tak więc konkretna czynność lepienia, tudzież dolepiania, uchodzić mogła za praktyczno-metonimiczny element metaforycznego sensu wyrażającego „ideę” trwałości, żywotności. Dla ukazania szerszego spektrum aksjologicznego wymienionych czynności wypada przytoczyć inny leksem pokrewny z leksemem [4].

[4a] ie. *loipos 'odpowiedni, stosowny', 'ozdobny': psł. lěpjša > pol. lepszy stopień wyższy do psł. lépъ 'ładny, piękny, dobry, odpowiedni'. Rozwój znaczenia ie. *loipos (< *loipey $\bar{\sigma}-$ 'lepić') byłby następujący: 'przylepiający się', 'dobrze przylegający' > 'pasujący', 'stosowny', 'odpowiedni' > 'dobry', 'ładny', por. lit. lipnùs 'lepki' 'miły, lagodny, laskawy'” .

Sensy waloryzujące proestetycznie czynności polegające zarówno na wygładzaniu, jak i na przylepianiu są dobrze poświadczone w tradycji greckiej.

[5] ie. *leiwos 'gładki, lepki': łac. lēvis 'gładki', grec. leios 'gładki'15. Przytoczone tu słowo greckie ma dość ściśle określoną konotację w estetycznej terminologii Platona. Platon kojarzył gładkość z miękkością przeciwstawioną szorstkiej twardości (Fedon 110d; Sofista 226c; Timajos 63c). Ponadto jest to gładkość mająca cechę specyficznej lepkości (Timajos $82 \mathrm{~d})^{16}$.

\footnotetext{
"' Gamkrelidze, Ivanov 1984, s. 632.

${ }^{12}$ Buck 1949, s. $630,1496$.

${ }^{13}$ Pokorny 1959, s. 670; Mann 1987, s. 673; Mallory, Adams 1997, s. 528; Sławski 1970, s. 271.

${ }^{14}$ Sławski 1970, s. 168, 169; Mann 1987, s. 704.

${ }^{15}$ Hofmann 1966, s. 176.

${ }^{16}$ Losev 1961, s. 59.
} 
Wydaje się, że lepkość i gładkość stanowiły kiedyś nierozdzielny kompleks w zbiorze jakości estetycznie doniosłych. Widać to nie tylko w przekazach rozwiniętej refleksji filozoficznej nad fenomenami estetycznymi, ale i w przytoczonych świadectwach leksykalnych, pozwalających poszukiwać źródeł wyobrażeń tego kompleksu w zamierzchłej przeszłości wspólnot indoeuropejskich. W takim kontekście można postawić tezę, że smarowanie naczyń ceramicznych dziegciem w okresie neolitu mogło - na poziomie motywacji magicznych i proestetycznych - stanowić jedną z archeologicznie uchwytnych podstaw późniejszego rozwoju wskazanych tutaj sensów i wyobrażeń. Należy zauważyć, że z leksemu [4] pochodzi polskie słowo lipa, oznaczające pierwotnie drzewo mające korę zdatną do wyrobu łyka, do oblepiania rozmaitych przedmiotów. Uwaga ta znajdzie swoje rozwinięcie w kolejnej części rozważań.

\section{B. ZDOBIENIE NACZYŃ SKRAWKAMI KORY}

Obok techniki zdobienia naczyń polegajacej na smarowaniu ich powierzchni dziegciem, z okresu neolitu znane są przykłady naklejania na ścianki naczynia fragmentów specjalnie przyciętej kory. Tego rodzaju zdobienie zostało poświadczone $w$ inwentarzu szwajcarskiej kultury Coratillod. Na naczyniach ceramicznych przypisanych tej kulturze występuje ornament w postaci aplikacji z kory brzozowej. Skrawki kory, wycięte na kształt trójkątów, prawdopodobnie osadzano na powierzchni garnków za pomocą lepiszcza dziegciowego ${ }^{17}$.

W przypadku tego sposobu zdobienia naczyń rysują się dwie uzupełniające się hipotezy, mogące ukazać rozwój waloryzacji proestetycznej, której motywacje są archeologicznie uchwytne w sferze dawnych technik zdobniczych. Pierwsza z tych hipotez postuluje uwzględnianie etnologicznego i etnolingwistycznego faktu, że w tradycji wielu wspólnot europejskich istniało wyobrażenie utożsamiające korę ze skórą, a także specyficzne utożsamienie pojemnika wykonanego ze skóry z naczyniem wykonanym z kory. Chodzi tu o wyeksponowanie wyobrażenia magicznego z doby „preceramicznej”, w ramach którego kora i skóra są wyposażone w określone, magicznie doniosłe „sprawności” czy też „zdolności”. W świetle hipotetycznego określenia tych „sprawności” bardziej zrozumiałe stają się kulturowe inspiracje wykonywania naczyń ze skóry i z kory - nawet w okresie upowszechnienia się technologii wyrobu naczyń ceramicznych. Druga z hipotez zmierza do ukazania „genealogicznego" związku dawnych wyobrażeń dotyczących wspomnianych „sprawności” kory i skóry, ich wykorzystania do wyrobu naczyń, z ich pozostałymi własnościami, stanowiącymi podstawę konstytuowania się późniejszych wartości estetycznych.

${ }^{17}$ Clark 1957, s. 247; Langer, Kośko 1999, s. 74. 


\section{B.1. PIERWOTNE WYOBRAŻENIA UTOŻSAMIAJĄCE KORĘ ZE SKÓRA}

Praktykowane w neolicie nacierane naczyń ceramicznych thustymi substancjami mogło na planie poczynań technicznych wykazywać wiele metonimicznych związków z konserwacją pierwotnych pojemników skórzanych. Warto dodać, że niektóre z najstarszych nazw garnków etymologicznie wywodzą się z nazw bukłaków. Pierwotne motywacje semantyczne tych nazw traktuja zasobnik skórzany jak obiekt mający własne i niewyczerpalne źródło ciagłego wzrostu. Wyobraźnia doby preceramicznej przypisująca naczyniom - poprzez odpowiednią kwalifikacje słowną immanentną zdolność do stałego powiększania swojej objętości (tak jak kora na drzewie i skóra na zwierzęciu), zdradza elementy „magii życzeniowej”" ${ }^{18}$. Procesualne widzenie rzeczy, przewidujące jej nieustanny wzrost, było w naoczności magicznej jednoczesnym nadawaniem tej rzeczy specyficznych „sprawności”. Tak więc kora, dzięki skojarzeniu ze skórą jako pojemnikiem, mogła być uważana za siedlisko preferowanych magicznie „dyspozycji”, które niejako indukowano w wytwarzane naczynie, np. poprzez owijanie łykiem, stosowanie aplikacji z kory lub poprzez smarowanie garnka dziegciem - tak jak smarowano pojemniki skórzane. Poza tym, naczynia ceramiczne nasączano tłuszczami i dziegciem nie tylko ze względu na kontynuację zabiegów epoki preceramicznej, ale być może także z uwagi na sposób doświadczenia ,piękna”, bliski wspomnianym wyobrażeniom wczesnogreckim.

[6] ie. *korā, *koryom 'skóra', *koros 'skóra okrycie' ${ }^{19}$. Najbliższe odpowiedniki to stind. cárman- 'skóra, okrycie, kora', łac. corium 'skóra, powłoka, kora', cortex 'kora, muszla, skorupka', stirl. coirt 'skóra, kora', pol. skóra, kora, tu należy także nazwa pojemnika korzec. Są to leksemy urobione od rdzeni *(s)kre-, *(s)kəre-, *(s)krē- 'kroić, ciąć' ${ }^{20}$. Dalsze nawiązania, np. fiń. keri 'biel rosnąca na brzozie po zerwaniu pierwszej warstwy kory', mordw. ker 'kora lipowa', kar' 'łapcie z łyka', wogul., mans. ker, keer 'kora', 'skorupka jajka', ost. kär 'kora łupinka', afroaz. * $q r(m)$ 'kora', alt. $k^{c} E / r$ 'ä 'kora' potwierdzają niezwykle archaiczną, zapewne epipaleolityczną metrykę tych formacji. Ich wspólnym źródłem byłby nostatycki morfem ${ }^{* *} K a ̈ r^{\prime} \ddot{a}$ 'kora' lub $* * k^{[h]} a r$-, $* * k^{[h]} \partial r$ 'skóra, okrycie, kora ${ }^{, 21}$.

[7] ie. * $g^{w} \overline{e i-},{ }^{*} g^{w} e y 2-,{ }^{*} g w \bar{I}-$ 'skóra, okrycie, kora', tu np. stind. jillas 'worek skórzany'. Najbliższe nawiązania nostratyckie: ugfiń. *koya 'powłoka, okrycie, skóra, kora', fiń. koja 'kora dębowa', karel. koja 'kora brzozowa', ural. koja 'kora, skóra, okrycie'. Podstawą rozwoju znaczenia tych formacji jest morfem nostratycki ${ }^{* *} k o j H a$ 'skóra, kora' lub ${ }^{* *} k^{\text {'w }} u y$-; ${ }^{* *} k^{\text {'w }}$ oy- 'zewnętrzne okrycie ze skóry, skóra, kora, łupina, skorupa'22.

\footnotetext{
${ }^{18}$ Kowalski 2000, s. 159.

${ }^{19}$ Mann 1987, s. 533, 536.

${ }^{20}$ Pokorny 1959, s. 938-947.

${ }^{21}$ Illič-Svitic 1971, hipoteza 217; Bomhard, Kerns 1994, hipoteza 247.

${ }^{22}$ Illič-Svitic 1971, hipoteza 169; Bomhard, Kerns 1994, hipoteza 348.
} 


\section{B.2. SKRAWKI KORY JAKO NOŚNIK \\ SENSÓW MAGICZNYCH I PROESTETYCZNYCH}

Aby przybliżyć krąg wyobrażeń generujących ewentualne sensy przypisywane korze, zwłaszcza korze brzozowej, wypada przyjrzeć się semantyce najstarszej indoeuropejskiej nazwy tego drzewa. W ten sposób uzyskamy wstępną orientację w zakresie potencjału waloryzacyjnego odzwierciedlonego w etymologii i w derywatach tej nazwy.

[8] ie. *bherəgos, *bherəgā 'brzoza': stind. bhürjas 'gatunek brzozy', łac. fraxinus 'jesion', dac. Bersovia 'las brzozowy', stnord. björk 'brzoza', lit. béržas 'brzoza', pol. brzoz $a^{23}$. Podstawa rozwoju znaczenia nazwy brzozy jest morfem pie. * $b^{[h]}$ erEk'- 'jaśnieć, błyszczeć' < nost. **bar-l**bor- 'jaśnieć, lśnić'24.

$\mathrm{Z}$ nazwą brzozy jest związana nazwa kory w językach germańskich, np. ang. bark, niem. Bork, co sugeruje, że musiało funkcjonować „technologiczne” definiowanie brzozy jako drzewa dostarczającego korę do wyrobu rozmaitych sprzętów. Nie zmienia to jednak faktu, że wyszczególnione tu nazwy są derywatami leksemów pierwotnie znamionujących jasny kolor kory tego drzewa. W związku z jasnością i bielą kory brzozowej można mówić o dwóch grupach sensów składających się na układ pierwotnej waloryzacji kulturowej.

Jedna grupa sensów dotyczy roli brzozy w tradycji mityczno-rytualnej i w folklorze ludów Europy. Zdaniem P. Friedricha brzoza już przed pięcioma tysiącami lat była żeńskim bóstwem Indoeuropejczyków, symbolem czystości magicznej, a potem występowała jako uosobienie nieskazitelności i dziewictwa ${ }^{25}$. Godny zauważenia pogląd o rytualno-magicznej czystości brzozy jako pierwotnej motywacji jej indoeuropejskiej nazwy lansują i dokumentują empirycznie T.N. Gamkrelidze i V.V. Ivanov ${ }^{26}$. W tradycji słowiańskiej poświadczony jest rozległy zakres sensów sakralnych przypisywanych brzozie w związku z jej białym kolorem ${ }^{27}$. Jeśli chodzi o tradycję germańska, to usiłowano nawet dokonać rekonstrukcji nazwy „bogini brzozowej" *Berkanō > goc. bairkana - bercna jako analogię w postaci Dea Berca$n a$ do teonimu Dea Vercana ${ }^{28}$.

Druga grupa sensów odnosi się do waloryzacji estetycznej. Należy w związku z tym dodać i podkreślić, że w językach celtyckich dawny rzeczownik ie. *bherĝt'jasność, połysk' (pokrewny z leksemem [8]) jest podstawą słów oddających znaczenia związane wyraźnie z osiagganiem „piękna”, np. śirl. bress 'piękno, piękny', irl. breágh 'piękny', wal. berth 'przyjemny, piękny'29. W wielu tradycjach indoeu-

\footnotetext{
${ }^{23}$ Delamarre 1984, s. 168.

${ }^{24}$ Bomhard, Kerns 1994, hipoteza 16; Pokorny 1959, s. 139; Rédei 1986, s. 66.

${ }^{25}$ Friedrich 1970, s. 30, 31.

${ }^{26}$ Gamkrelidze, Ivanov 1984, s, 620.

${ }^{27}$ Vinogradova, Usačeva 1995.

${ }^{28}$ Lehmann 1986, s. 66.

${ }^{29}$ Mann 1987, s. 73.
} 
ropejskich „piękno" często było metonimicznym korelatem blasku i jasności. Z tego powodu fakt, że społeczeństwa celtyckie hołdowały podobnym wyobrażeniom, nie budzi specjalnego zdumienia. Interesujące jest dla nas tylko to, że spośród wielu pozostających do wyboru możliwości leksykalnych, społeczeństwa te obrały na wyrażenie ,piękna" słowa pochodne od leksemów oznaczających pierwotnie biel i połysk kory brzozowej. Jest to zatem mocna przesłanka przemawiająca za istnieniem już w odległych pradziejach ważnego związku między wykorzystywaniem kory brzozowej i kształtowaniem zmysłu estetycznego. Taki punkt widzenia na kulturotwórczą rolę ( $w$ zakresie specyfikacji niektórych sensów estetycznych) „praktycznego" niegdyś wykorzystywania kory przez pradziejowych wytwórców znajduje wsparcie w kolejnej atestacji.

[9] ie. *leub(h)-ō 'rozcinać, rozdzierać, rozwarstwiać' > 'wykonywać przedmioty z łyka i kawałków zdartej kory': psł. lupiti > pol. tupić, psł. lubъ 'kora lipowa', 'naczynia wykonane z kory', 'przybory zrobione z łyka' > pol. tub, tubianka, śdn. lōp 'naczynie drewniane', stnord. laupr 'kosz', łac. liber 'książka' < 'pasmo kory, na którym pisano' 30 .

Stosowana przez wczesnotradycyjne wspólnoty neolityczne technika rozwarstwiania, złuszczania skóry przeznaczonej do wyrobu pojemników była podstawową metodą nadawania skórze trwałości, nieprzemakalności i połysku ${ }^{31}$. Znamienne, że technika rozwarstwiania kory, przycinania pasków skóry, itp. legła u podstaw leksykalnych określeń dotyczących ważnych aksjologicznie sfer doświadczenia kulturowego. Dlatego możemy mówić o dwumianie aksjologicznym obejmującym sensy magiczne i proestetyczne związane ze słownictwem odnoszącym się do tej klasy działań. Otóż w germańskich derywatach ie. *leub(h)-ō dominują znaczenia związane $\mathrm{z}$ magią lecznicza, $\mathrm{z}$ przygotowywaniem wywarów ziołowych lub napojów $z$ soku kory, np. stang. lybb 'czary', stnord. lyf 'ziele lecznicze', swn. luppi 'zioła, czary $^{, 32}$. Natomiast kontynuanty greckie zostały włączone w zakres wyspecjalizowanej terminologii estetycznej, np. grec. leptós 'delikatny, lekki, elegancki' < 'odłupany, przycięty', leptourge ō 'sporządzać misterne, delikatne rzeczy', leptourg $\overline{\hat{s}}$ 'kunsztownie zrobiony ${ }^{33}$. Przykładowo Dionizjusz z Halikarnasu w swej charakterystyce stylu sztuki Lyziasza, Kalamidosa i Kallimachosa używa słowa lepótês na określenie lekkości i delikatności ${ }^{34}$.

Istnieje jeszcze jeden ważny aspekt proestetyczno-magicznego wykorzystywania kory brzozowej. Otóż inicjał pierwotnej nazwy brzozy dał początek gockiej nazwie znaku runicznego bercna ${ }_{2}$ mającego fonetyczną wartość $b^{35}$. W perspekty-

\footnotetext{
${ }^{30}$ Pokorny 1959, s. 690.

${ }^{31}$ Semenov, Korobkova 1983, s. 137.

${ }^{32}$ Lehmann 1986, s. 237.

${ }^{33}$ Hofmann 1966, s. 177.

${ }^{34}$ Pollitt 1974, s. 206.

${ }^{35}$ Lehmann 1986, s. 66.
} 
wie „genealogii" pradziejowej wytwórczości związek dziegciu i kory ze zdobnictwem naczyń znowu zyskuje wspólne znaczenie i kulturowo przypisaną rangę. Kora brzozowa, zanim stała się materiałem przeznaczonym do pisania, pierwotnie długo służyła za tworzywo do nanoszenia znaków o charakterze magicznym i ornamentacyjnym. Jest wielce prawdopodobne, że takie magiczno-proestetyczne przeznaczenie skrawków kory znamionuje pewien etap jej specjalnego wykorzystywania. Być może nanoszenie wycinków kory na naczynia neolityczne, zdobione przy innej okazji rytym ornamentem poprzedzającym znaki pisma, należy odczytywać jako pierwotny wyraz względnie jednolitej dziedziny wyobrażeń. W takim razie również dziegieć można do pewnego stopnia uważać za jedną z substancji, której pradziejowe sposoby użycia zadecydowały o powstaniu specjalnych barwników i werniksów używanych obecnie w profesjonalnej działalności artystycznej.

\section{B.3. INDOEUROPEJSKA NAZWA POJEMNIKA OKLEJONEGO KORĄ BRZOZOWA}

Dostępna dokumentacja etnologiczna obfituje w świadectwa ukazujące wielorakie wykorzystywanie kory brzozowej w wytwórczości rozmaitych przyborów, przedmiotów użytkowych, zwłaszcza pojemników. Do ubiegłego stulecia niemal w każdym zakątku Europy można było zetknąc się z przejawami długotrwałej tradycji wytwarzania naczyń drewnianych, zasobników wykonywanych z kory ${ }^{36}$. Jeśli chodzi o interesujący nas tu przypadek użytkowania naczyń ceramicznych oklejonych korą brzozową, to zaskakująco ciekawe pod tym względem są lingwistyczne atestacje notowane w językach słowiańskich. Warto zwrócić uwagę na nazwy łyka lub specjalnie przygotowanej kory, które nawiązują do indoeuropejskiej nazwy brzozy, np. psł. berstb 'wierzchnia kora brzozy', 'łyko' > pol. brzost. Ponadto istnieje nazwa pojemnika psł. berstěnъ 'pojemnik z brzostu', 'naczynie z kory brzozowej', 'naczynie ceramiczne oklejone korą brzozowa' > pol. brzościany 'wykonany z kory brzozowej', pol. dial. brześcian 'stary rozbity garnek opleciony łykiem brzozowym', brus. dial. бересцén 'garnek opleciony korą brzozową' oraz szczególnie godny uwagi ros. берестян 'naczynie oplecione korą brzozową', 'dziegieć $z$ kory brzozowej ${ }^{37}$. Przytoczone przykłady sugerowałyby wykorzystywanie kory brzozowej w pierwszym rzędzie do naprawy uszkodzonych naczyń ceramicznych. Nie można jednak wykluczyć, że w zapisie lingwistycznym zachował się ślad pradziejowego zwyczaju oklejania garnków łykiem lub skrawkami kory brzozowej. W tym kręgu wyobrażeń pozostawałoby również stosowanie masy dziegciowej do uszczelniania lub do zdobienia naczyń ceramicznych, na co pośrednio wskazują dane $z$ języka rosyjskiego.

\footnotetext{
${ }^{36}$ Moszyński 1967, s. 244, 265, 280, 281.

${ }^{37}$ Stawski (red.) 1974, s. 208, 209.
} 
W świetle powyższych świadectw i ze względu na zbieżności semantycznomorfologiczne wiążące psł. berstěn z z takimi formacjami, jak łac. fraxinus i goc. * bairkana, dopuszczalna jest próba rekonstrukcji lokalnego archetypu indoeuropejskiego w postaci *bherHĝtēno-s. Jedynie na podstawie danych słowiańskich można precyzować zakres semantyczny tego leksemu i przypisać mu jako jedno ze znaczeń 'pojemnik z kory brzozowej' 'naczynie ceramiczne oklejone korą brzozową lub owinięte łykiem brzozowym' 'naczynie mające jakiś związek z dziegciem brzozowym'.

\section{PODSUMOWANIE}

Zaprezentowana próba wykorzystania materiału lingwistycznego miała na celu uwiarygodnić hipotezę archeologiczną o znaczącej roli wykorzystywania dziegciu $\mathrm{i}$ kory $\mathrm{w}$ zdobnictwie naczyń neolitycznych. Na podstawie dostępnego materiału leksykalnego można w przybliżeniu określić zespół archaicznych wyobrażeń związanych $\mathrm{z}$ archeologicznie dokumentowanymi aspektami neolitycznej wytwórczości. Nie ulega wątpliwości, że czynności polegające na nadawaniu rzeczom połysku, jasności oraz trwałości od bardzo dawna nabierały określonego sensu proestetycznego. Godne podkreślenia jest to, że jedną z dziedzin praktycznej działalności wytwórczej, mogącej urzeczywistniać te sensy, było właśnie użytkowanie kory, szczególnie brzozowej i lipowej, a także wykorzystywanie metonimicznie związanego z kora brzozową dziegciu lub lepiszcza. Taką identyfikację sugerują świadectwa lingwistyczne. Określony hipotetycznie przekrój ewentualnych wyobrażeń dotyczących wymienionych tu działań nie może być oceniany jako bezdyskusyjny ,ideowy" ekwiwalent faktów odnotowanych na gruncie archeologii. Niemniej przekrój ten wytycza pewien istotny, choć jeszcze niewyspecyfikowany potencjał waloryzacyjny (określający sensy magiczno-proestetyczne), tkwiący w tej akurat dziedzinie działań wytwórczych niektórych wspólnot neolitycznych.

\section{SKRÓTY JĘZYKOWE}

$\begin{array}{ll}\text { afroaz. } & \text { - afroazjatycki } \\ \text { ałt. } & \text { - attajski } \\ \text { ang. } & \text { - angielski } \\ \text { brus. } & \text { - bialoruski } \\ \text { dac. } & \text { - dacki } \\ \text { dial. } & \text { - dialektalny } \\ \text { fiń. } & \text { - finski } \\ \text { goc. } & \text { - gocki } \\ \text { grec. } & \text { - grecki } \\ \text { het. } & \text { - hetycki } \\ \text { ie. } & \text { - indoeuropejski } \\ \text { irl. } & \text { - irlandzki }\end{array}$

$\begin{array}{ll}\text { karel. } & \text { - karelski } \\ \text { lit. } & \text { - litewski } \\ \text { łac. } & \text { - taciński } \\ \text { mans. } & \text { - mansyjski } \\ \text { mordw. } & \text { - mordwiński } \\ \text { niem. } & \text { - niemiecki } \\ \text { nost. } & \text { - nostratycki } \\ \text { ost. } & \text { - ostiacki } \\ \text { pie. } & \text { - praindoeuropejski } \\ \text { pol. } & \text { - polski } \\ \text { psł. } & \text { - prastowiański } \\ \text { stang. } & \text { - staroangielski }\end{array}$

stind. - staroindyjski

stirl. - staroirlandzki

stnord. - staronordycki

swn. - staro-wyskoko-niemiecki

śdn. - średnio-dolno-niemiecki

śirl. - średnioirlandzki

ugfiń. - ugrofinski

ural. - uralski

wal. - walijski

wogul, - wogulski 


\section{IBLIOGRAFIA}

B o m hard A.L., Kerns J.C.

1994 The Nostratic Macrofamily. A Study in Distant Linguistic Relationship, Berlin - New York.

B u c k C.D.

1949 A Dictionary of Selected Synonyms in the Principal Indo-European Languages. A Contribution to the History of Ideas, Chicago.

Cl a rk J.G.D.

1957 Europa przedhistoryczna. Podstawy gospodarcze, Warszawa.

Delamarre X.

1984 Le vocabulaire indo-européen. Lexique étymologique thématique, Paris.

Forbes R.J.

1956 Chemical, culinary and cosmetic arts, (w:) A history of technology (red. Ch. Singer, E.J. Holmyard, A.R. Hall), vol, I, Oxford, s. 238-298.

Friedrich P.

1970 Proto-Indoeuropean trees. The arboreal system of a prehistoric people, Chicago.

Gamkrelidze T.V., I vanov V.V.

1984 Indoevropejskij jazyk i indoevropiejcy, t. II, Tbilisi.

$\mathrm{H}$ of $\mathrm{m}$ a $\mathrm{n} \mathrm{n}$ J.B.

1966 Etymologisches Wörterbuch des Griechischen, München.

Il 1 i č-S v i t i č V.M.

1971 Opyt sravnenija nostratičeskich jazykov (semitochamitskij, kartvelskij, indoevropejskij, uralskij, dravidyjskij, altajskij). Sravnitelnij slovar', t. 1, Moskva.

Ingarden $\mathrm{R}$.

1970 Zagadnienie systemu jakości estetycznie doniostych, Studia z estetyki, t. III, Warszawa. s. 288-315.

Kowalski A.P.

2000 Genealogia sztuk II. Naczynie w stowniku kultury „nostratyckiej”. Analiza magicznego doświadczenia rzeczy [Zus. Genealogie der Kunst. Gefaße im Wortschatz der „nostratischen" Kultur. Analyse der magischer Sacherfahrung], (w:) Eidolon. Kultura archaiczna w zwierciadle wyobrażeń, stów i rzeczy (red. H. van den Boom, A.P. Kowalski, M. Kwapiński), Gdańsk, s. 149-166.

2001 Myślenie przedfilozoficzne. Studia z filozofii kultury i historii idei, Poznań.

L anger J.J., Kośk o A.

1999 Z badań nad zastosowaniem dziegciu w ornamentyce ceramiki neolitycznej. Perspektywa Niżu Polski [Sum. Studies on the Application of Birch Tar in the Ornamentation of the Neolithic Pottery from the View-point of the Polish Lowland], „Folia Praehistorica Posnaniensia", t. IX, s. 63-77.

Leh man n W.P.

1986 A Gothic Etymological Dictionary, Leiden.

Leroi-Gourhan A.

1971 Evolution et techniques. L'homme et la matière, Paris.

Lose $v$ A.F.

1961 Estetičeskaja terminologia Platona, (w:) Iz istorii estetičeskoj mysli drevnosti $i$ sredneve kovija, Moskva, s. 17-62.

Mallory J.P., A d a m s D.Q.

1997 Encyclopedia of Indo-European Culture, London, Chicago. 
Man n S.E.

1987 An Indo-European Comparative Dictionary, Hamburg.

Meringer $R$.

1913 Einige primäre Gefühle des Menschen, ihr mimischer und sprachlicher Ausdruck, „Wörter und Sachen", Bul. V, s. 129-171.

Moszyński K.

1967 Kultura ludowa Stowian, t. I, Kultura materialna. Warszawa.

Pokorny J.

1959 Indogermanisches etymologisches Wörterbuch, Bern, München.

Pollitt J.J.

1974 The Ancient View of Greek Art: Criticism, History, and Terminology, New Haven, London.

Réde i K.

1986 Zu den indogermanisch-uralischen Sprachkontakten, Wien.

S e m e nov S.A., Korobkova G.F.

1983 Technologija drevniejšich proizvodstv. Mezolit-eneolit, Leningrad.

S ławski F.

1970 Slownik etymologiczny języka polskiego, t. IV, Kraków.

Sławs k i F. (red.)

1974 Slownik prastowiański, t. I, Wroclaw.

V inogradova L.N., Us a č v a V.V.

1995 Bierioza, (w:) Enciklopedičeskij slovar'. Slavjanskaja mifologija, Moskva, s. 44-47.

Walde A., Hof man $n$ J.B.

1938 Lateinisches etymologisches Wörterbuch, Bd. I, A-L, Heidelberg.

1954 Lateinisches etymologisches Wörterbuch, Bd. II, M-Z, Heidelberg.

\section{IMPORTANCE OF BIRCH TAR AND BARK IN THE DECORATION OF NEOLITHIC VESSELS.}

A LINGUISTIC CONTRIBUTION TO THE PREHISTORY OF AESTHETICS

\section{Sum mary}

A study of the Neolithic pottery, undertaken by archaeologists and natural scientists, made it possible to discern that some prehistoric agrarian communities of the Northern European Plain used birch tar and bark in vessels' decoration. This fact is important from the point of view of the prehistory of aesthetics. Some traditional ways of beauty and charm qualification derive from names of techniques of vegetable dye application as well as from names given to the shine of birch bark. More particularly, they derive from lubrication of vessel surfaces by grease or tar. This observation has been confirmed in the Greek tradition. For Homer, beauty was identified with liquid, ready to be lubricated coat, which gives glossiness to objects (Odyssey XVIII, 192-193: kalà kàthêren ämbrisiô).

In the reconstructed Indo-European vocabulary one can find examples revealing a relationship between the use of tar or pitch and decoration. According to T.V. Gamkrelidze and V.V. Ivanov a semantic and morphological convergence of words such as *peukã 'pine' $\sim$ *piks 'pitch, resin' $\sim$ *peik 'to color, to paint' implies that tar and pitch were used for decoration purposes. In materials of the Neolithic culture Cortaillod of Switzerland one can find examples of birch bark fragments sticking onto the clay vessels. The relation among the act of grease lubrication, coloring, and sticking using tar and bark in 
decoration is revealed by the following Indo-European lexemes: *leipō 'to mould, to smear' *loipos 'appropriate, decorative'. The following words are their derivatives: Slavic lěpb 'pretty, beautiful' > Polish lepszy, lipa 'a tree providing bark for production of different objects'. Another lexeme that confirms these relations is as follows: Indo-European *leub( $h)$ - $\delta$ 'to cut, to separate, to stratify' > 'to produce objects from inner bark and fragments of torn off bark', from which derives Greek leptourgeñ ' to produce fine and delicate objects', which was then used in later aesthetic terminology leptós 'delicate, light, elegant'. It is worth pinpointing that the derivative of beauty in Celtic languages comes from IndoEuropean *bhergt- 'glow, glossiness' that is identical with Indo-European name of birch and birch bark *bheregã. In later historical traditions birch bark was used for writing. It is possible that covering the Neolithic vessels by bark fragments, which were in other instances decorated by band ornaments being a predecessor of writing characters, should be interpreted as a primeval expression of a coherent set of representation. By the same token, use of tar for vessel decoration should be treated as a technique that initiated the use of special dyes and varnishes in the professional artistic activity.

While taking into consideration a hypothesis about the existence of expression referring to the use of tar and bark for vessel decoration, one might hypothetically reconstruct a name of this kind of vessel as *bherHgtêno-s 'a container made of birch bark' 'a clay vessel stuck over by birch bark or wrapped by birch inner bark' 'a vessel somehow related to birch tar'.

The linguistic evidence presented above is certainly not an adequate representation of expressions accompanying the use of tar and bark in the decoration of Neolithic vessels. It should be treated as a supplement of archaeological observations. Thanks to linguistic and archaeological studies one can look for prehistoric contexts of formation of later aesthetic categories.

Translated by Arkadiusz Marciniak 